\title{
PSYCHE
}

VOL. XXIV

DECEMBER, 1917

No. 6

\section{THE TEMPORARY SOCIAL PARASITISM OF LASIUS SUBUMBRATUS VIERECK. ${ }^{1}$}

\section{By William Morton Wheeler.}

During the past summer, while studying the ants of the Sacramento Mountains, at Cloudcroft, N. M. (alt. 9,000 ft.), I had an opportunity to observe the method of colony formation employed by Lasius (Formicina) umbratus Nyl. subsp. subumbratus Viereck. L. umbratus has long been known as a circumpolar species comprising several races, or subspecies and varieties, the names and known geographical distribution of which are recorded in the following list:

\section{Palearctic Forms.}

L. umbratus subsp. umbratus $\mathrm{Nyl}$. subsp. mixtus Nyl. var. mixto-umbratus Forel var. umbrato-affinis Ruzsky

Nearctic Forms. subsp. mixtus var. aphidicola Walsh subsp. subumbratus Viereck subsp. speculiventris Emery subsp. vestitus Wheeler subsp. minutus Emery
Northern and Alpine Eurasia from Britain to Japan.

Russia.

Canada, Central and Atlantic States.

British America, Rocky Mts.

Known only from New Jersey.

Known only from Idaho.

Central and Atlantic States.

In Europe, according to Wasmann and Donisthorpe, the var. mixto-umbratus is more common than the typical umbratus or mixtus, between which it is intermediate in size, color and pilosity. In the Eastern United States aphidicola is certainly the most

1 Contributions from the Entomological Laboratory of the Bussey Institution, Harvard University. No. 136. 
abundant form of umbratus. The subspecies speculiventris and vestitus are imperfectly known, the latter from a single female specimen, the former only from the types taken many years ago by Pergande at Caldwell, N. J. The subspecies minutus is very sporadic. During the past eight years I have found only a single colony of it in the vicinity of Boston. The types of the subspecies subumbratus were taken by Professor Cockerell at Beulah, N. M. (alt. 8,000 ft.). I have taken it at Williams, and on Mt. Lemmon in the Santa Catalina Range $(9,000 \mathrm{ft}$.), Ariz., at Cloudcroft, N. M. (9,000 ft.), Lake Tahoe, Calif. (8,000 ft.), near Ottawa, Ontario, and Hull, Quebec and have seen specimens from Digby and Bedford, Nova Scotia. It is therefore the most boreal and stenothermal of all the North American subspecies of umbratus and, as I have stated in a former paper (1917), properly belongs to the Canadian zone.

To the ethologist umbratus is of unusual interest, because in Europe it is a temporary parasite of $L$. niger and in turn serves as the host of $L$. (Dendrolasius) fuliginosus, which is therefore a true temporary social hyperparasite. The young umbratus queen is adopted by a colony of niger workers, which bring up her brood. Eventually these workers die off, probably in the course of four or five years, and the umbratus colony, now pure, becomes very populous. Then it may in turn adopt a queen of fuliginosus, the offspring of which eventually supplant the umbratus colony. In both cases the host queens are eliminated, probably by being assassinated either by their own workers or by the parasitic queens. The various phases in the development of the umbratus and fuliginosus colonies have been studied by European myrmecologists. The occasional occurrence of mixed colonies of umbratus and niger and umbratus and fuliginosus was noted by Schenck, Adlerz, Forel, Wasmann and de Lannoy, but Emery and Forel in 1908 first suggested that they might be interpreted as arising from temporary social parasitism. Later Crawley and Donisthorpe fully demonstrated the truth of this conjecture by showing that the typical umbratus is parasitic on the typical niger, the subspecies mixtus on the subspecies alienus, and that umbratus regularly functions as the temporary host of fuliginosus.

Although North America is so rich in umbratus forms, no one has hitherto been able to prove from observations in the field that any 
of them is parasitic on some one of our varieties of $L$. niger. I have repeatedly found deälated queens of aphidicola in small cavities under stones as if in the act of founding colonies independently in the same manner as most ants, but never with brood. Nor have I ever been able to find a mixed colony of $L$. niger var. americanus and aphidicola, even in Illinois where both forms are common in the same localities. The only indication that any American form of umbratus may be a social parasite is furnished by some specimens of subumbratus collected by $\mathrm{Mr}$. W. Reiff in Nova Scotia and some experiments by Tanquary on minutus. At Bedford, near Halifax, Mr. Reiff took six deälated subumbratus queens from three colonies of what I recorded at the time (1910) as "the large yellowish form of Lasius niger var. neoniger Emery." Since the discovery of Pergande's types of Alaskan ants I can now state definitely that this variety is sitkaësis. As Reiff's specimens were not accompanied by notes, the parasitism of subumbratus could only be conjectured. Tanquary introduced successively some eighty-eight of the small, active queens of minutus into twenty different colonies of $L$. americanus, nearcticus, brevicornis, claviger and interjectus and obtained one case of adoption. This was in a colony of eight workers and a large number of cocoons of americanus. He concludes that "although one adoption out of 88 attempts is a small percentage, yet I think the ease with which this queen was adopted is very suggestive, and taken together with the facts mentioned above, namely the sporadic occurrence of the species, the very large number of females produced, the small size of the females, the fact that these females have not been seen in the act of founding a colony and one additional fact that may be mentioned, the mimetic coloration of the females (the color of these females is exactly the same as that of the darker form of americanus), I think justifies us in concluding that the queen of this species is in all probability, temporarily, parasitic upon the common L. americanus."

My observations at Cloudcroft leave no doubt concerning the parasitism of the subspecies subumbratus on two forms of $L$. niger, the var. sitkaënsis Pergande and the var. neoniger Emery. The former, as I have recently shown (1917), is the common form of niger at higher altitudes and latitudes from Alaska to Maine and Nova Scotia and southward along the ranges of the Sierra Nevada 
and Rocky Mountains. The worker and female of this variety are large, brown or yellowish brown, with numerous erect or suberect hairs on the legs and antennal scapes. It passes over into the var. neoniger, which is smaller and darker, but has hairy legs and scapes, unlike our common and more xerothermic var. americanus, which closely resembles the European alienus in having the legs and scapes merely finely pubescent. At Cloudcroft sitkaënsis is everywhere abundant in the pine forests at an altitude of 9,000 to 9,500 feet, and nests by preference under large stones. The females and workers have a peculiar and rather agreeable aroma, which is much stronger than that of americanus and much like the odor of subumbratus. On rocky slopes, exposed to the sun, especially along the edges of the alpine meadows, the typical sitkaënsis is replaced by neoniger and forms intermediate in size and coloration. At altitudes of 7,000 to 7,500 feet or at higher elevations in very warm, dry situations the var. americanus and forms transitional to neoniger are not uncommon. At Cloudcroft I failed to find subumbratus below 9,000 feet. Its colonies are very populous and live under large stones, usually in the shade of the pines. Its habits, like those of the other subspecies of umbratus, are decidedly hypogæic. It does not make carton like the European umbratus. This is generally true also of our eastern aphidicola. I have, however, found a few colonies of this ant at Colebrook, Conn., and Ottawa, Ontario, nesting in dark brown carton nests in the centers of rotten logs.

The observations proving that the young queens of subumbratus establish their colonies with the aid of sitkaënsis and neoniger workers may now be transcribed from my note-book:

July 3 and 5. Four colonies of subumbratus were found under large stones. Two were of considerable size and the superficial chambers of the nests were full of black males and golden yellow females ready for the marriage flight.

July 8 . The marriage flight of subumbratus must have occurred on July 6 or 7 as there were numerous deälated females running about among the stones on an open, sunny slope where many of the stones covered nests of neoniger. My son Ralph assisted me in carefully turning over the stones and examining these nests. In one area, about 200 feet in diameter, nearly every nest had from one to five deälated subumbratus queens running about in the large 
shallow superficial chambers. By shading the chambers, which were occupied by numerous neoniger workers and cocoons, the behavior of the yellow queens could be readily studied. They ran in and out of the chambers and galleries leading into the soil and, when accosted by the neoniger workers, made peculiar supplicatory movements with the antennæ, precisely like those of Formica consocians queens seeking adoption in nests of $\boldsymbol{F}$. incerta. The neoniger workers, however, resented the intrusion and frequently seized the legs and antennæ of the queens, though they soon released their hold. The queens thus liberated often escaped from the nest and hid under stones near it or even in unfrequented nooks in the superficial chambers of the nest itself. On several occasions we saw a queen seize a neoniger worker, carry it out of the nest and release it uninjured. One queen was seen to snatch up a worker cocoon, carry it out of the nest and conceal it under an adjacent pebble. This is very suggestive of the behavior of the young Formica sanguinea queen that has entered a nest of $\boldsymbol{F}$. fusca, but though it undeniably shows an interest on the part of the subumbratus queen in the neoniger brood, her method of colony formation is not that of $\boldsymbol{F}$. sanguinea, for we soon discovered a depauperate neoniger colony which had undoubtedly adopted a subumbratus queen. The latter was moving to and fro very slowly and amicably in the midst of several neoniger workers and their cocoons in a small recess under a stone. The ants were watched for some time and behaved precisely like members of a single colony. That the queens are nevertheless occasionally treated much more severely by the neoniger workers, is apparent from the fact that we found a few recently killed and one partially eaten in the superficial chambers of some of the nests.

July 9. Visited another rocky slope and an adjoining pine forest about a mile east of Cloudcroft and two miles from the locality of yesterday's observations. Under the stones covering neoniger and sitkaënsis nests there were many deälated subumbratus queens eagerly seeking adoption. The following three colonies showed clearly that some of the queens had been or were being accepted:

1. A populous sitkaënsis colony under several large contiguous stones among the pines. The superficial galleries of the nest were filled with workers and worker, male and female cocoons nearly 
ready to hatch. Under two of the stones a couple of subumbratus queens was found, each lurking quietly in a little cavity at the edge of a mass of cocoons nearly filling a large, shallow superficial chamber.

2. A similar but even larger sitkaënsis nest, also under a pile of stones, under three of which subumbratus queens were found. One of the queens was in a small cavity at the edge of a heap of cocoons while each of the others was resting on the very center of a collection of cocoons nearly as large as my palm. These queens had certainly been adopted and the picture presented was precisely like that of the recently adopted Formica consocians queens mounted on the cocoons and surrounded and fondled by the workers of $\boldsymbol{F}$. incerta (Wheeler 1906). When the nest was disturbed the queens hurried into the galleries and disappeared in the soil. They had evidently become strongly negatively heliotactic, unlike queens that are still running about on the soil immediately after the marriage flight.

3. A fine sitkaënsis nest under a single large stone among the pines had an adopted subumbratus queen surrounded by dozens of workers in the center of a pile of worker and female cocoons nearly as large as my hand. She quickly slipped into a burrow and was only recovered by digging down into the soil to a depth of more than six inches. In this nest a few of the female sitkaënsis pupæ were naked, i.e., not enclosed in cocoons.

Further search in the same locality brought to light two mixed colonies consisting of subumbratus and sitkaënsis workers. I failed to find the queens of the former species, which were probably pressent but hiding deep in the soil. The failure to find them is not surprising as one very rarely secures the mother queen of a fully developed colony of any of our species of Lasius without extensive and very careful excavation of the nest.

The foregoing observations show that the subumbratus queen has to acquire the brood odor of the host before she can be accepted. She therefore lurks very near the cocoons in a small earthen cavity and somewhat later, in the early stage of adoption, like Formica consocians, takes up a position on the brood. This renders her immune to attack by the host workers and gradually accustoms them to her presence. That adoption can be secured in very populous and flourishing colonies of sitkaënsis is shown by the 
observations of July 9. Nevertheless these observations throw no light on three interesting problems, which may be briefly considered:

1. The first problem relates to the elimination of the host queen, evidently a conditio sine qua non of successful colony formation by such temporary social parasites as subumbratus. The elimination is supposed to be effected in one of three ways: Either adoption succeeds only in host colonies that have already lost their rightful queen through death by accident or old age, or the queen is killed by her own workers after and because the young parasitic queen has secured their allegiance, or the latter assassinates the host queen. The first hypothesis seems to be supported by the above described adoption of a subumbratus queen in a depauperate colony of neoniger, although it is by no means certain that this colony was queenless. The large sitkaënsis colonies containing recently adopted subumbratus queens, however, would seem to support the second or third hypothesis. In regard to this problem in the European umbratus, Donisthorpe (1915) says: "No cases are known of the host queen and the parasite living together in a nest, so unless a female can only be adopted by a queenless colony, it must sometimes happen that a female is accepted by a colony already possessing a queen of its own species. In such a case the intruder must either kill the rightful queen herself, as the female of (nonBritish) Bothriomyrmex kills the queen of her host Tapinoma or the workers of the host species must themselves assassinate their own queen, as do the workers of Tetramorium coespitum when they have accepted a female Anergates atratulus." He adds, however, that "Crawley confined several queens of umbrata with queens of nigra and the latter were always killed by the former, which although a little the smaller, is stronger and possesses more powerful mandibles." It seems to me that the morphological peculiarities suggested by Donisthorpe, namely the much broader and larger head and stronger mandibles so characteristic of the female of all umbratus forms as compared with the same sex of niger, indicate very clearly that the parasite actually decapitates the host queen in much the same manner as Bothriomyrmex decapitans was seen by Santschi (1906) to decapitate the Tapinoma erraticum queen and the queen Wheeleriella santschii, the queen of Monomorium solomonis (Forel 1906). 
2. The fact that one of the sitkaënsis colonies observed July 9 contained two fully adopted subumbratus queens and one on the verge of adoption suggests the question as to whether all three queens would survive as mothers of the compound colony or whether two of them would be subsequently eliminated. This question can, of course, be answered only by further investigation. But as the various species of the genus Lasius hitherto observed are decidedly haplometrotic it seems probable that at least in the majority of cases of adoption of several subumbratus queens by a sitkaënsis or neoniger colony, the number must be subsequently reduced to unity either by combats among the queens or by the regulatory intervention of the workers.

3. My field observations leave some doubt as to whether sitkaënsis or neoniger is the true, or normal host of subumbratus. Indirect evidence, however, points to the former variety, since the queens and workers of subumbratus are much more like the corresponding phases of sitkaënsis in size and coloration and since pure adult colonies of these forms prefer the same shady environment and have the same hypogæic habits. Reiff's Nova Scotia specimens of subumbratus queens from sitkaënsis nests may also be cited in this connection. L. neoniger, therefore, would be an unusual or perhaps recently acquired host, and the conditions would be comparable to those of the typical European umbratus, whose normal host is the typical niger, though it is occasionally parasitic, as Donisthorpe has shown (1915), on the subspecies alienus, the normal host of mixtus.

The rather large number of observed cases of adoption of subumbratus seems to indicate that the queen of this subspecies is specially favored as compared with the queens of some other temporary social parasites (e. g. Formica rufa and truncicola) by the possession of peculiar myrmecophilous characters (trichomes, exudate organs). I believe that the beautiful golden yellow color and pilosity of the subumbratus queen, which make it resemble the queens of Formica consocians, ciliata, criniventris and oreas, the smaller stature and the delieate odor may be designated as such characters. In this connection I may call attention to the queen of Lasius crinitus, long ago described by Frederick Smith from Cashmir, as being in all probability a temporary social parasite on $L$. niger or one of its varieties. I have recently seen a few queens 
of crinitus from Sikkim and was struck by their remarkable resemblance in color and pilosity to the queens of the Colorado $F$. ciliata. The source of the delicate odor of subumbratus, of the strong, lemon-verbena odor of our North American Lasii of the subgenus Acanthomyops and of the peculiar pungent, sweetish odor of the Eurasian fuliginosus, is worthy of further investigation. Meinert and Bönner believe that in umbratus and fuliginosus it comes from the salivary glands. Forel had previously traced it to the head as this portion of the body when crushed emitted a more violent aroma than the thorax and gaster. I have been under the impression that it might originate in the epinotal glands. Since it is so powerful and pervasive that it even saturates the walls of the nest a renewed and careful investigation may be required before its precise source in the body of the insect is known.

\section{Literature.}

1886. Adlerz, G. Myrmekologiska Studier II. Svenska Myror och deras Lefnadsförhållanden. Bih. K. Svensk. Vet.-Akad. Handl. 11, 18, 1886, pp. 1-329, 7 pls.

1915. Bönner, W. Der temporäre soziale Hyperparasitismus von Lasius fuliginosus und seine Beziehungen zu Claviger longicornis Müll. Zeitschr. f. wiss. Insekt. Biol. 11, 1915, pp. 14-20.

1909. Crawley, W. C. Queens of Lasius umbratus Nyl., Accepted by Colonies of Lasius niger L. Ent. Month. Mag. (2) 20, 1909, pp. 94-99.

1910. Crawley, W. C. Workers of Lasius flavus (? L. umbratus) among Lasius fuliginosus. Ent. Rec. 22, 1910, pp. 67-69.

1913. Crawley, W. C. and Donisthorpe, H. St. J. K. The Founding of Colonies of Queen Ants. Trans. Second Intern. Ent. Congr. (1912) 1913, 2, pp. 11-7\%.

1911. Donisthorpe, H. St. J. K. Further Observations on Temporary Social Parasitism and Slavery in Ants. Trans. Ent. Soc. London, 1911, pp. 175-183.

1913. Donisthorpe, H. St. J. K. On Some Remarkable Associations between Ants of Different Species. Rep. Lancast. Ches. Ent. Soc. 36 (1912), 1913, pp. 38-56.

1915. Donisthorpe, H. St. J. K. British Ants, Their Life-History 
and Classification. Plymouth, William Brendon \& Son. 1915.

1911. Donisthorpe, H. St. J. K. and Crawley, W. C. Experiments on the Formation of Colonies of Lasius fuliginosus Females. Trans. Ent. Soc. London, 1912, pp. 664-672.

1908. Emery, C. Remarques sur l'existence de Lasius mixtus dans les fourmilières de L. fuliginosus. Ann. Soc. Ent. Belg. 52, 1908, pp. 182-183.

1906. Forel, A. Moeurs des Fourmis parasites des Genres Wheeleria et Bothriomyrmex. Rev. Suisse Zoöl. 14, 1906, pp. $51-69,6$ text-figs.

1908. Forel, A. Lettre à la Société Entomologique de Belgique. Ann. Soc. Ent. Belg. 52, 1908, pp. 180-181.

1908. de Lannoy, F. Notes sur le Lasius niger et le Lasius fuliginosus. Ann. Soc. Ent. Belg. 52, 1908, pp. 47-53.

1906. Santschi, F. A propos des moeurs parasitiques temporaires des Fourmis du genre Bothriomyrmex. Ann. Soc. Ent. France, 75, 1906, pp. 363-392.

1852. Schenck, A. Beschreibung nassauischer Ameisenarten. Jahrb. Ver. Naturk. Nassau, 8, 1, 1852, pp. 3-149.

1911. Tanquary, M. Experiments on the Adoption of Lasius, Formica and Polyergus Queens by Colonies of Alien Species. Biol. Bull. 20, 1911, pp. 281-308.

1908. Wasmann, E. Weitere Beiträge zum sozialen Parasitismus und der Sklaverei bei den Ameisen. Biol. Central. 28, 1908, pp. 257-271, 289-306, 321-333, 353-382, 417-441.

1909. Wasmann, E. Ueber gemischte Kolonien von LasiusArten. Zoöl. Anzeig. 35, 1909, pp. 129-141.

1910. Wasmann, E. Nachträge zum sozialen Parasitismus und der Sklaverei bei den Ameisen. Biol. Centralbl. 30, 1910, pp. 453-464, 475-496, 515-524.

1906. Wheeler, W. M. On the Founding of Colonies by Queen Ants, with Special Reference to the Parasitic and Slavemaking Species. Bull. Amer. Mus. Nat. Hist. 22, 1906, pp. 33-105, 7 pls.

1910. Wheeler, W. M. The North American Forms of Lasius umbratus Nylander. Psyche, 17, 1910, pp. 235-243.

1917. Wheeler, W. M. The Mountain Ants of Western North America. Proc. Amer. Acad. Sci. 52, 1917, pp. 457-569. 

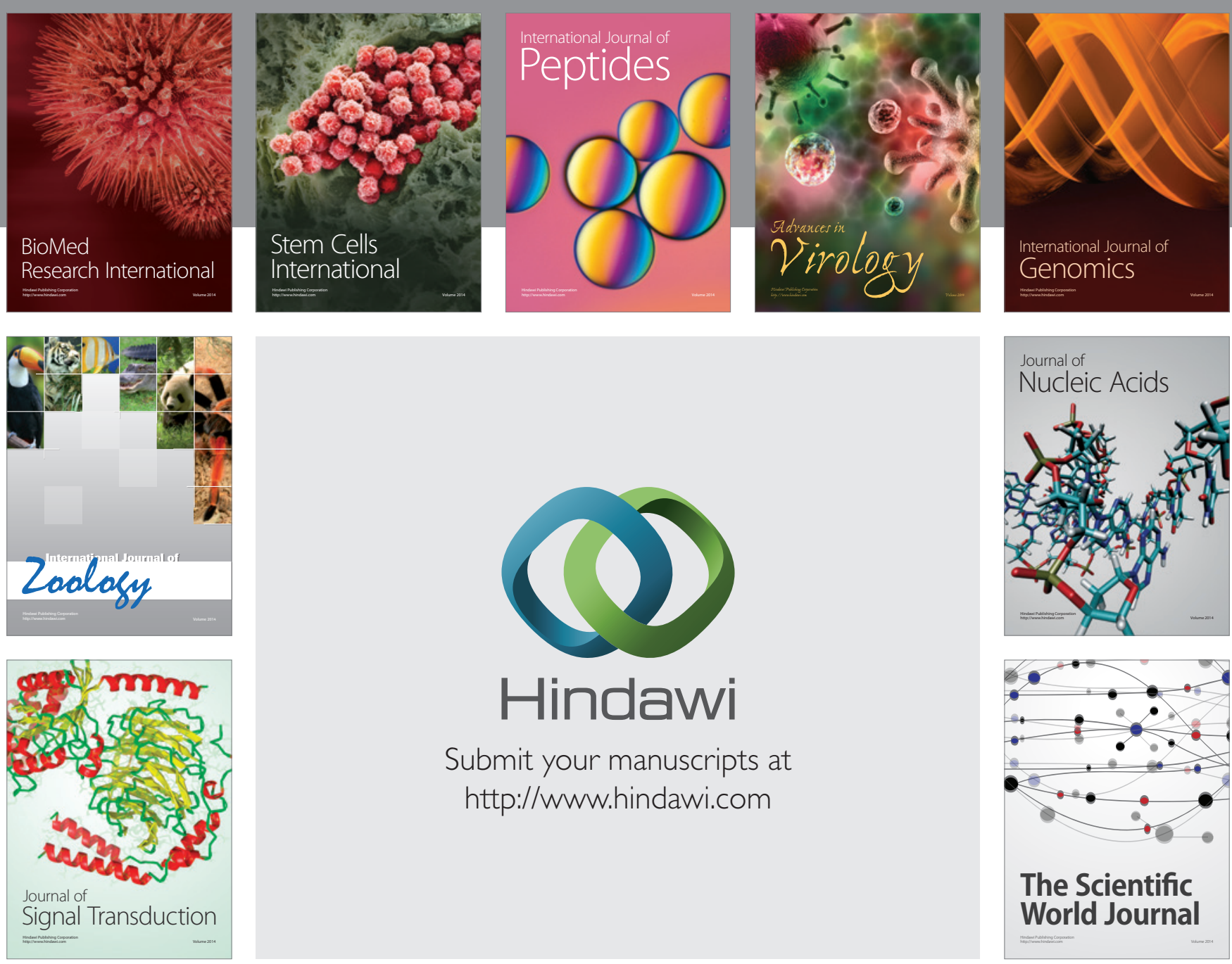

Submit your manuscripts at

http://www.hindawi.com
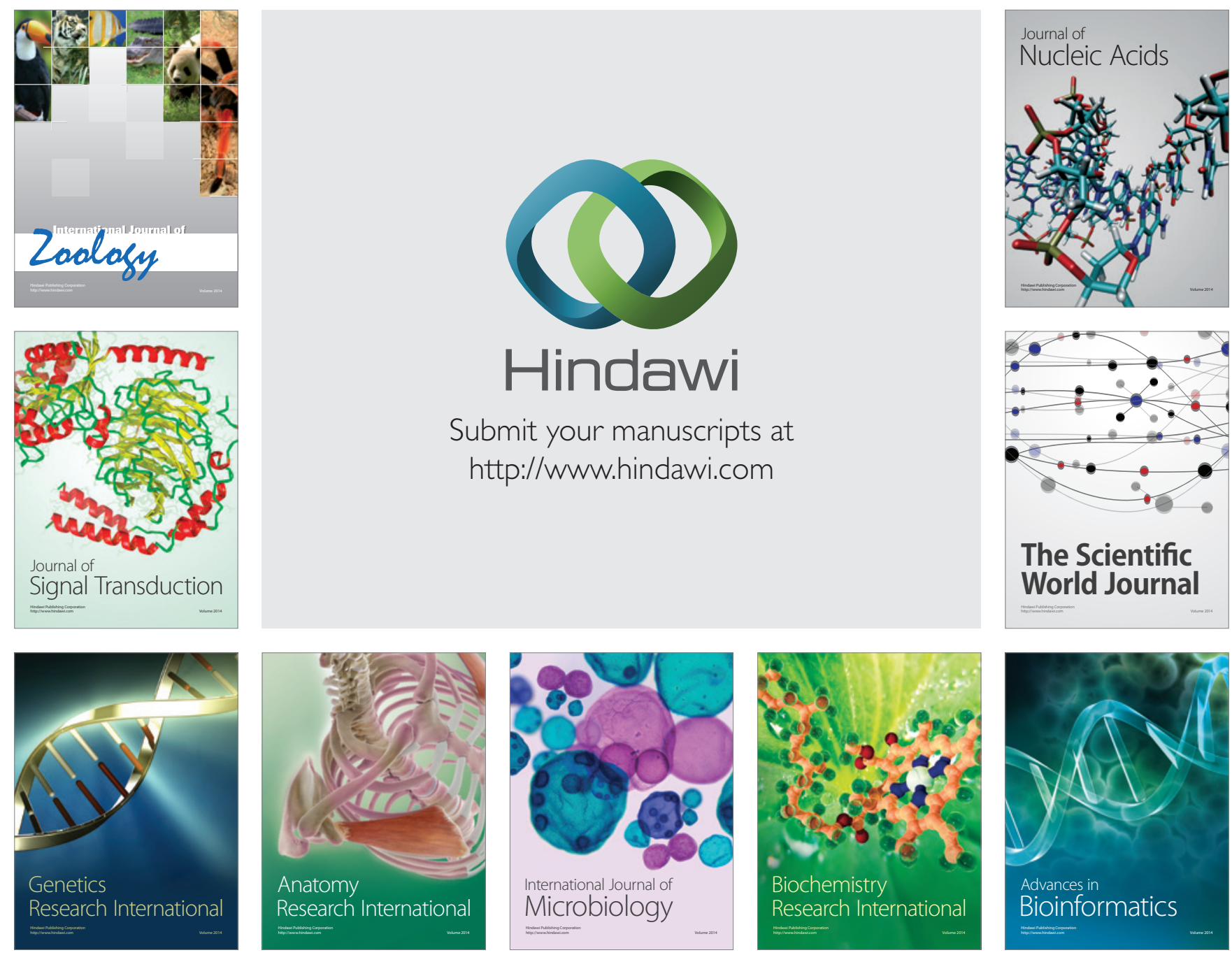

The Scientific World Journal
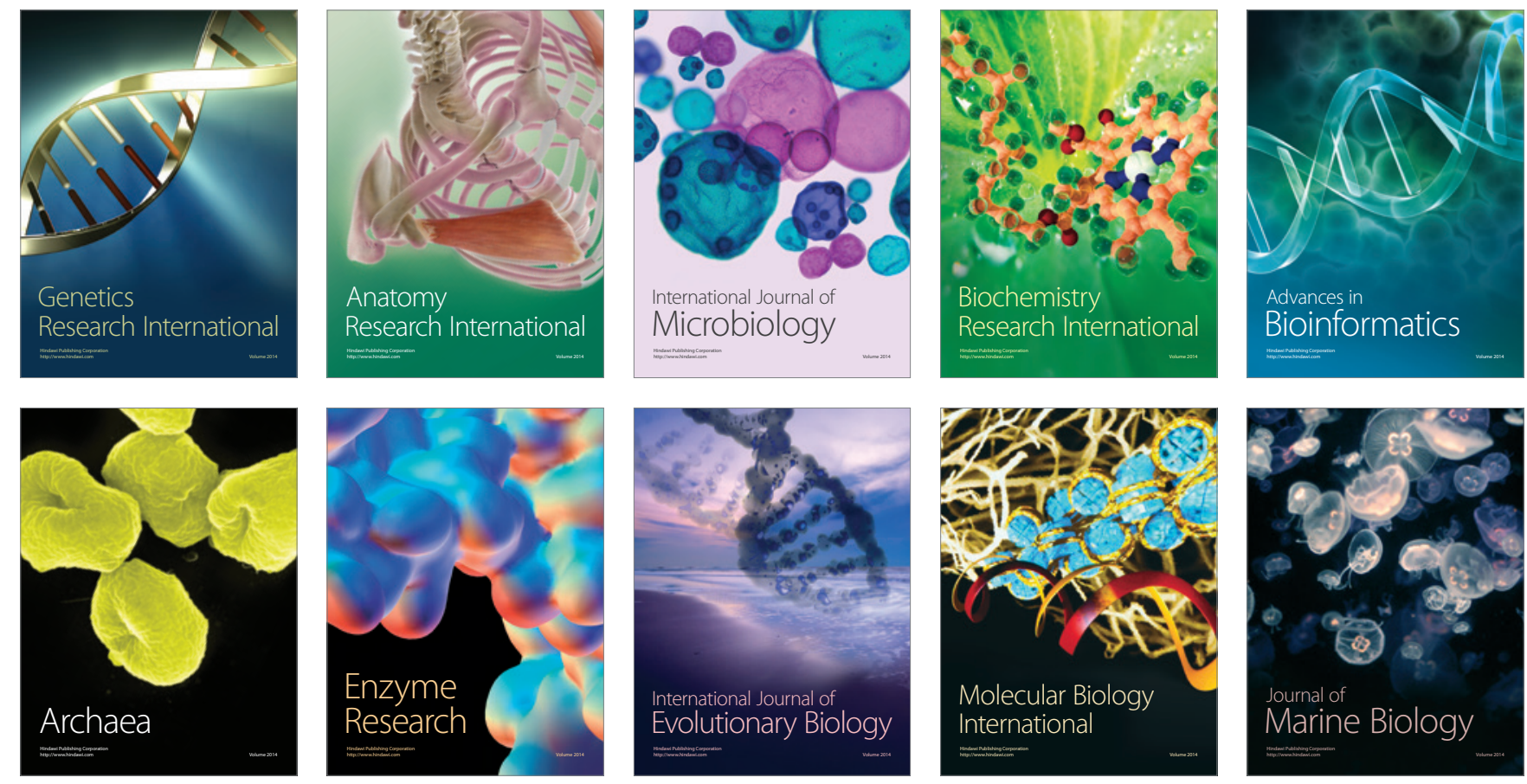